\title{
GGU's aktiviteter i 1990
}

\section{Martin Ghisler}

Direktør

GGU's aktiviteter i 1990 har været præget af en ny strategi på råstofområdet, som sigter på en mangedobling af private selskabers efterforskningsvirksomhed, med henblik på at råstofudnyttelse i fremtiden bliver et af de centrale erhverv i Grønland.

GGU har en vigtig rolle at spille i denne udvikling. Institutionen skal ved egne undersøgelser skabe det nødvendige geologiske fundament for koncessioneret råstofefterforskning. Men desuden skal GGU formidle relevante geologiske data fra både tidligere efterforskningsaktiviteter og egne undersøgelser til olie- og mineindustrien i en overskuelig og let tilgængelig form.

I forbindelse med GGU's informationsvirksomhed over for den internationale olie- og mineindustri kan nævnes følgende:

- opbygningen af geologiske databaser er videreført, og som led heri er alle vigtige mineralfund fra Vestgrønland registreret;

- etablering af et borekernearkiv i København omfattende kerner fra tidligere efterforskningsboringer (Maarmorilik, Mesters Vig, Ivittuut m.v.) er afsluttet;

- en ny publikationsserie omfattende tematiske kort fra råstofgeologisk interessante områder er påbegyndt med et sat på 57 geologiske, geofysiske og geokemiske kort i digitaliseret form dækkende området mellem Nuuk og Maniitsoq;

- en ny informationsservice over for olieindustrien er påbegyndt ved udsendelse af halvårlige nyhedsbreve omhandlende oplysninger og resultater af relevans for kulbrinteområdet (GHEXIS).

Der er gennemført en række forskningsprojekter vedr. de geologiske ressourcer i både Vest- og $\emptyset_{\text {st- }}$ grønland, dels ved feltaktiviteter, dels ved bearbejdelse af tidligere indsamlet materiale. I alt deltog 43 videnskabelige og tekniske medarbejdere i GGU's ekspeditioner i 1990.

I Nordøstgrønland bragtes den geologiske oversigtskortlægning af området mellem $75^{\circ}$ og $78^{\circ} \mathrm{N}$ til afslutning efter 3 feltsæsoner. Med udgangspunkt fra en teltbase ved Hvalrosodden vest for Danmarkshavn undersøgtes især området mellem $77^{\circ}$ og $78^{\circ} \mathrm{N}$, bl.a. med henblik på regionens råstofpotentiale. Ekspeditionen blev gennemført i samarbejde med biologiske og ar- kæologiske undersøgelser finansieret af Grønlands Hjemmestyre, og hele gruppen omfattede over 40 deltagere.

De oliegeologiske undersøgelser af området mellem $72^{\circ}$ og $75^{\circ} \mathrm{N}$ baseret på feltarbejde i $1986-89$ blev afsluttet og afrapporteret. De vigtigste resultater blev præsenteret på et internationalt oliegeologisk møde i Troms $\emptyset$ og publiceres i relevante fagtidsskrifter.

Efter afslutningen af ARCO's seismiske undersøgelser i Jameson Land og opsigelse af koncessionen til udgangen af 1990 har GGU gennemført en selvstændig vurdering af områdets oliemuligheder på grundlag af selskabsdata og GGU's egne undersøgelser med henblik på at skabe interesse for en eventuel videreførelse af olieefterforskningen ved andre selskaber.

I området midtvejs mellem Scoresbysund og Ammassalik har GGU på vegne af Råstofforvaltningen for Grønland ført tilsyn med canadiske koncessionshaveres boringer og undersøgelser af guld- og platinforekomsterne ved henholdsvis Skærgårdshalvø og Kap Edvard Holm.

Med finansiel støtte fra Råstofforvaltningen blev der i Vestgrønland indsamlet over $3285 \mathrm{~km}$ nye seismiske data ud for kysten mellem $62^{\circ}$ og $70^{\circ} \mathrm{N}$. Desuden er en næsten tilsvarende mængde tidligere indsamlede data $(2670 \mathrm{~km})$ fra 1977 blevet reprocesseret. Begge initiativer sigter på at skabe fornyet interesse for området hos internationale olieselskaber, som forlod området $\mathrm{i}$ slutningen af 70'erne efter omfattende seismiske undersøgelser og 5 'tørre' boringer. På land indledtes fornyede oliegeologiske undersøgelser på Nuussuaq.

Med henblik på lokalisering af mulige mineralforekomster påbegyndtes geokemisk prøveindsamling af elvsand i området vest og nord for Søndre Strømfjord.

I Maarmorilik deltog GGU på Råstofforvaltningens vegne i tilsynet med nedlukningen af zink-bly minen, og opbevaringsværdigt arkivmateriale og udvalgte borekerner blev sikret i GGU for en fremtidig råstofefterforskning. Desuden gennemførtes geokemisk opfølgningsarbejde og prøveindsamling i et område nord for Maarmorilik, hvor der er konstateret indikationer på guld.

GGU deltog i en feltunders $\varnothing$ gelse iværksat af Grønlands Hjemmestyre vedrørende muligheden for at an- 
vende grønlandske forekomster til eventuel produktion af facade- og gravsten.

Glaciologiske undersøgelser blev gennemført flere steder i Vestgrønland, primært med henblik på udnyttelse af vandkraft, men også som et dansk/grønlandsk bidrag til den internationale klimaforskning. Unders $\varnothing$ gelserne ved Tasersiaq syd for Søndre Strømfjord afsluttedes efter 10 års indsamling af massebalancedata. Studier af forholdene nord for Ilulissat blev videreført i samarbejde med internationale forskningsgrupper. I Buksefjordsområdet ved Nuuk udvidedes de glacio- logiske undersøgelser til de sydlige dele af vandkraftområdet.

I 1990 har GGU udgivet to geologiske kort fra henholdsvis Sydøstgrønland og Nordgrønland og tre kortbladsbeskrivelser til tidligere publicerede kort. I egne serier er desuden udkommet en bulletin, tre rapporter samt ni bidrag i Open File-serien og et i Thematic Map-serien. Som resultat af GGU-aktiviteter er der publiceret 54 artikler i internationale fagtidsskrifter (se s. 66).

\title{
Review of the Survey's activities in 1990
}

\author{
Martin Ghisler
}

Director

Negotiations on a new strategy for exploration and utilisation of the mineral resources in Greenland were started during the year between the Greenland Home Rule Authorities and the Danish state. This strategy aims to encourage the mining and oil industry to intensify exploration activities in Greenland. In connection with this new approach, the Geological Survey of Greenland (Grønlands Geologiske Undersøgelse, GGU) has continued and developed initiatives to facilitate ready access to relevant geological, geophysical and geochemical data held by the Survey. Emphasis has been placed on the following:

- enhancement of a number of existing geological data bases, including the addition of data covering West Greenland to the Mineralization Data Bank;

- completion of the drill core storage facility in Copenhagen, containing material from earlier mining and exploration activities;

- publication of the first issue of a new thematic map series, comprising 57 digitalised maps of the NuukManiitsoq area of West Greenland;

- introduction of a new information service for the oil industry with publication of a biannual newsletter (GHEXIS).

Field projects in 1990 were carried out with a total of 43 participants. The largest group worked from a base west of Danmarkshavn in North-East Greenland, and completed a three year programme of activity in the region between $75^{\circ}$ and $78^{\circ} \mathrm{N}$. Studies included geol- ogical mapping, geochemical sampling, and glaciology and Quaternary geology. An evaluation of the hydrocarbon potential between latitudes $72^{\circ}$ and $75^{\circ} \mathrm{N}$ in North-East Greenland, based on field work in 1986-89, was also concluded.

Geological reconnaissance on Nuussuaq in West Greenland identified targets for sedimentological, palynological and source rock studies planned for 1991 and 1992. Systematic stream sediment sampling was undertaken in the area west and north of Søndre Strømfjord. Geochemical sampling took place north of Maarmorilik, including continued work on earlier identified gold anomalies.

A seismic acquisition programme on the southern part of the West Greenland shelf between latitudes $62^{\circ}$ and $70^{\circ}$ yielded significant new data (3285 line kilometres). In addition reprocessing of $2670 \mathrm{~km}$ of reflection seismic data from the Labrador Sea acquired in 1977 was undertaken.

Glacier hydrological studies and hot water drilling north of Jakobshavn contribute valuable information to hydropower development studies, as well as contributing to international research on climatic change. Mass-balance studies were terminated at Tasersiaq near Søndre Strømfjord after 10 years of continuous measurements. Collection of glacier-hydrological data was continued south of Buksefjorden, where Greenland's first hydropower station is under construction.

GGU participated in a field and laboratory study 